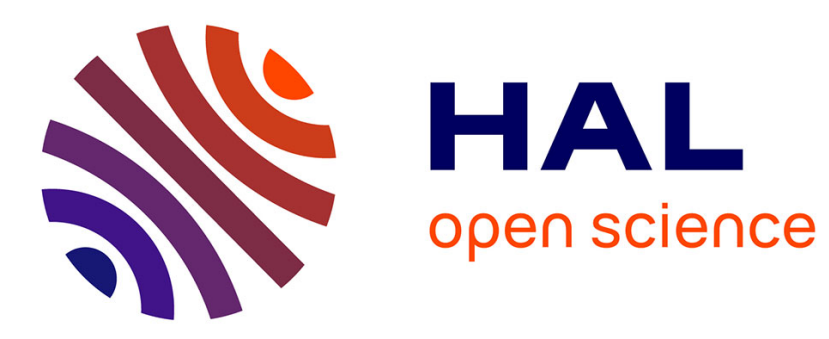

\title{
Is Procalcitonin a usefull biomarker for the risk stratification of facial cellulitis?
}

Chloé Bertolus, Thomas Schouman, Adeline Aubry, Pierre Hausfater

\section{To cite this version:}

Chloé Bertolus, Thomas Schouman, Adeline Aubry, Pierre Hausfater. Is Procalcitonin a usefull biomarker for the risk stratification of facial cellulitis?. Journal of Cranio-Maxillofacial Surgery, 2016, 44 (8), pp.995-997. 10.1016/j.jcms.2016.05.023 . hal-01331100

\section{HAL Id: hal-01331100 https://hal.sorbonne-universite.fr/hal-01331100}

Submitted on 13 Jun 2016

HAL is a multi-disciplinary open access archive for the deposit and dissemination of scientific research documents, whether they are published or not. The documents may come from teaching and research institutions in France or abroad, or from public or private research centers.
L'archive ouverte pluridisciplinaire HAL, est destinée au dépôt et à la diffusion de documents scientifiques de niveau recherche, publiés ou non, émanant des établissements d'enseignement et de recherche français ou étrangers, des laboratoires publics ou privés. 


\section{Is Procalcitonin a usefull biomarker for the risk stratification of facial}

\section{cellulitis?}

Chloé Bertolus ${ }^{1,2} \mathrm{MD}, \mathrm{PhD}$, Thomas Schouman ${ }^{1} \mathrm{MD}$, Adeline Aubry ${ }^{3} \mathrm{MD}$, Pierre Hausfater

$$
{ }^{2,3} \mathrm{MD}, \mathrm{PhD}
$$

${ }^{1}$ Oral and maxillo-facial surgery department, hôpital Pitié-Salpêtrière, AP-HP, Paris

${ }^{2}$ Sorbonne Universités-UPMC Univ Paris-06, Paris France

${ }^{3}$ Emergency department, hôpital Pitié-Salpêtrière, AP-HP, Paris France

Department to which the work should be attributed: Emergency Department, Pr Pierre Hausfater, MD, PhD, hôpital Pitié-Salpêtrière and UPMC, 83 boulevard de I'hôpital 75651, Paris Cedex 13 France

Corresponding author: Pr Pierre Hausfater, Emergency Department, hôpital PitiéSalpêtrière and UPMC, 83 boulevard de l'hôpital 75651, Paris Cedex 13 France

Tél : (33) 142177240

Fax : (33) 142177412

Email : pierre.hausfater@aphp.fr

Source of support: None 


\section{Abstract: (187 words)}

Background: facial cellulitis is an infectious disease that may require emergency surgical drainage based on clinical assessment. To date, no biological marker has been reported to be useful for risk stratification. Procalcitonin (PCT) is a diagnostic and prognostic sepsis biomarker. We aimed to study the usefulness of PCT dosage for the risk-stratification of facial cellulitis.

Patients and methods: This was a monocentric prospective study conducted in a referral center for maxillofacial emergencies. Patients with a diagnosis of facial cellulitis were included and underwent a PCT measurement at admission. The main criterion was the requirement for surgical drainage.

Results: 70 consecutive patients were included in a 7 -months period, mean age $35 \pm 14$ years. Surgical drainage was required for 48 patients (68\%). Serum PCT concentrations were strictly negative in most patients (median [IQR]: $0.05 \mu \mathrm{g} / 1$ [0.05;0.10]). Only 6 patients (9\%) had PCT values above the clinical threshold of $0.25 \mu \mathrm{g} / \mathrm{L}$. At a threshold of $0.1 \mu \mathrm{g} / \mathrm{l}$, PCT was $30 \%$ sensitive and $100 \%$ specific for surgical drainage requirement.

Conclusion: PCT level usually remains in a low range in facial cellulitis and seems to have a limited added value for risk stratification. 


\section{Introduction}

Facial cellulitis, mostly from odontogenic origin, is an urgent diagnosis. It is defined by the infection of the cellular adipose tissue located in the aponeurotic spaces of the face (Kimura and Pien 1993, deVicente-Rodriguez 2004,). Although early clinical stages may be easily cured by antibiotics, complications as cervical abscesses (precluding airway vacuity), mediastinitis, necrotizing fasciitis, thrombosis of the cavernous sinus and septic shock can be life-threatening (Lee et al 2010, Thikkurissy et al 2010, Nicot et al 2014, Olsen and van Winkelhoff 2014). Actually, the decision for incision and surgical drainage of facial cellulitis is based essentially on the clinical examination helped by facial computerized tomography scan but not on biological variables. Procalcitonin (PCT) is a biomarker of bacterial infection and has been reported to be useful in the emergency department (ED), either for sepsis diagnosis, severity assessment or antibiotic stewardship (Hausfater et al 2007, de Kruif et al 2010, Freund et al 2012, Schuetz et al 2012, Hausfater 2014).

In this study, we hypothesized that PCT may have an incremental added value to routine clinical data to predict the severity of facial cellulitis.

\section{Patients and methods}

This prospective observational study was conducted from March 2010 to September 2010 in the ED of an 1800-bed tertiary care academic hospital. Our ED is also the referral center during night shifts for maxillofacial emergency for the Paris area population (12 million people). Patients assigned to the maxillofacial surgeon during night shifts are admitted in the ED. 
Because of the study design (observational study), the local ethical committee waived inform consent (Comité de Protection des Personnes, CPP IdF VI).

The criterion for inclusion was each patient with a diagnosis of facial cellulitis made in the ED by the maxillofacial surgeon. The patients included underwent venous blood sampling according to usual local practice, except that a sample was sent to the laboratory for PCT dosage (Kryptor PCT ${ }^{\circledR}$, ThermoFisher Scientific BRAHMS, Hennigsdorf, Germany). The ED physician and the maxillofacial surgeon were both blinded to PCT results. A standardized clinical form summarizing the clinical characteristics of the facial cellulitis episode was filled by the treating maxillofacial surgeon. The patients were followed up until the ED discharge or discharge from hospital in case of admission.

The main criterion of judgment was the need for a surgical drainage. Secondary criteria of judgment were a hospital length of stay $>$ mean + standard deviation and/or need for reoperation. We hypothesized that, to exhibit an incremental added value to routine clinical data, PCT should have an area under receiver operating characteristic of at least 0.75 for the main criteria of judgment.

Statistical analysis

Data are expressed as mean \pm standard deviation (SD) for Gaussian variables, median and $25 \%$ to $75 \%$ interquartile range for non-Gaussian variables, or number and percentage for nominal variables with $95 \%$ confidence interval. Normality was assessed using the Kolmogorov-Smirnov test. Diagnostic variables (sensitivity, specificity) were calculated with their $95 \%$ confidence 
intervals (CI). Receiving operator characteristics (ROC) curves were constructed, and their areas under the curves were calculated.

\section{Results}

During the study period, 82 patients with a facial cellulitis were enrolled. For 2 patients major clinical data were missing, and for 10 patients no PCT sample was available. The characteristics of the 70 remaining patients are summarized in table 1 . All cellulitis were odontogenic. There were 37 men and 33 women, mean age $35 \pm 14$ years (extremes: 15-85). Trismus (33\%) and odynophagia (24\%) were the two most frequent associated local signs. No patient had dyspnea, mediastinitis or septic shock and no death was registered. All but 9 patients (13\%) were hospitalized with a median hospital stay duration of 3 [3-5] days. Surgical drainage was required for 48 patients (68\%), two of them underwent reoperation.

Serum PCT concentrations were strictly negative in most patients (table 1) with a median [IQR] of $0.05 \mu \mathrm{g} / 1[0.05 ; 0.10]$. Only 6 patients (9\%) had PCT values above the clinical threshold of $0.25 \mu \mathrm{g} / \mathrm{L}$. This concerned 5 of 48 patients (10\%) requiring surgical drainage versus 1 of $22(4 \%)$ who did not, and 3 of 8 patients (37\%) meeting the secondary criteria of judgment (reoperation and/or length of hospital stay above mean $+\mathrm{SD})$ versus 3 of $62(5 \%)$ who did not. At a threshold of $0.1 \mu \mathrm{g} / \mathrm{l}$, PCT was $30 \%$ sensitive (95\% CI: 19-44) and $100 \%$ specific (95\% CI: $84-100)$ for surgical drainage requirement. The PCT area under the ROC curves were 0,61 ( $0.47-0.71)$ and $0.74(0.44-0.89)$ for the main and secondary criteria of judgment respectively. 


\section{Discussion}

We report in this study that serum PCT concentrations are usually in the negative range in odontogenic facial cellulitis. To our knowledge, this is the first report of PCT values in patients with facial cellulitis. Although the patients with high PCT values were more prone to require surgical drainage, reoperation, or a prolonged length of hospital stay, our data do not support the use of this biomarker for the risk-stratification of facial cellulitis.

Facial cellulitis is an infectious disease due to the effraction of pathogenic bacteria from the oral cavity toward the aponeurotic spaces of the face (de Vicente-Rodriguez 2004, Kouassi et al 2011, Huy 2013). Clinical manifestations are related to the location of infected collections themselves but also to the surrounding inflammatory process. PCT is a biomarker of systemic bacterial infection and may not rise in strictly localized infectious process like appendicitis or pyelonephritis (Hausfater et al 2002, Yu et al 2013, Shaikh et al 2015). Another putative explanation for low PCT values in our cohort of facial cellulitis is that $27 \%$ were taking nonsteroidal anti-inflammatory drugs at admission. This may have altered the host systemic inflammatory response. However, experimental endotoxin studies on healthy volunteers have reported conflicting results and notably that ibuprofen, but not corticosteroids, may conversely increase serum calcitonin-precursors levels (Preas et al 2001, de Kruif et al 2008).

The outcome of facial cellulitis is directly in relation with the rapidity of diagnosis and care, as deep life-threatening collections may not be obvious clinically (Lee et al 2010, Thikkurissy et al 2010). Actually, head and neck CT-scan contributes mostly to the identification of purulent collections. However, the decision to perform it is still based on the clinical evaluation. To date, no biological variables have proven to be useful for the risk-stratification of facial cellulitis and 
our data do not support the dosage of PCT in this context.

\section{Conclusion}

Serum PCT concentrations usually remain in the low range in facial odontogenic cellulitis and seem to have a limited added value for risk stratification.

\section{References}

de Kruif MD, Lemaire LC, Giebelen IA, Struck J, Morgenthaler NG, Papassotiriou J, Peter J. Elliott PJ, van der Poll T: The influence of corticosteroids on the release of novel biomarkers in human endotoxemia. Intensive Care Med 34:518-522, 2008.

de Kruif MD, Limper M, Gerritsen H, Spek CA, Brandjes DPM, ten Cate H, Patrick M. Bossuyt PM, Reitsma PH, van Gorp ECM: Additional value of procalcitonin for diagnosis of infection in patients with fever at the emergency department. Crit Care Med 38:457-463, 2010.

de-Vicente-Rodríguez JC : Maxillofacial cellulitis. Med Oral Patol Oral Cir Bucal 9 Suppl 133$138 ; 126-33,2004$.

Freund Y, Delerme S, Goulet H, Bernard M, Riou B, Hausfater P: Serum lactate and procalcitonin measurements in emergency room for the diagnosis and risk-stratification of patients with suspected infection. Biomarkers 17:590-596, 2012. 
Hausfater P, Garric S, Ayed SB, Rosenheim M, Bernard M, Riou B. Usefulness of procalcitonin as a marker of systemic infection in emergency department patients: a prospective study. Clin Infect Dis 34:895-890, 2002.

Hausfater P, Juillien G, Madonna-Py B, Haroche J, Bernard M, Riou B: Serum procalcitonin measurement as diagnostic and prognostic marker in febrile adult patients presenting to the emergency department. Crit Care 11:R60, 2007.

Hausfater P: Biomarkers and infection in the emergency unit. Med Mal Infect 44:139-145, 2014.

Huy PTB: Cervico-facial necrotizing fasciitis. Rev Prat 63:755-758, 2013.

Kimura AC, Pien FD: Head and neck cellulitis in hospitalized adults. Am J Otolaryngol 14:343$349,1993$.

Kouassi YM, Janvier B, Dufour X, Bouche G, Klossek J-M: Microbiology of facial cellulitis related to dental infection. Med Mal Infect 41:540-545, 2011.

Lee JW, Immerman SB, Morris LG: Techniques for early diagnosis and management of cervicofacial necrotising fasciitis. J Laryngol Otol 124:759-764, 2010.

Nicot R, Hippy C, Hochart C, Wiss A, Brygo A, Gautier S, Caron J, Ferri J, Raoul G: Do antiinflammatory drugs worsen odontogenic cervico-facial cellulitis? Rev Stomatol Chir Maxillofac Chir Orale115:e31-36, 2014.

Olsen I, van Winkelhoff AJ: Acute focal infections of dental origin. Periodontol 2000 65:178189, 2014. 
Preas HL, Nylen ES, Snider RH, Becker KL, White JC, Agosti JM, Suffredini AF: Effects of anti-inflammatory agents on serum levels of calcitonin precursors during human experimental endotoxemia. J Infect Dis 184:373-376, 2001.

Shaikh N, Borrell JL, Evron J, Leeflang MMG: Procalcitonin, C-reactive protein, and erythrocyte sedimentation rate for the diagnosis of acute pyelonephritis in children. Cochrane Database Syst Rev 1:CD009185, 2015.

Schuetz P, Müller B, Christ-Crain M, Stolz D, Tamm M, Bouadma L, Luyt CE, Wolff M, Chastre J, Tubach F, Kristoffersen KB, Burkhardt O, Welte T, Schroeder S, Nobre V, Wei L, Bhatnagar N, Bucher HC, Briel M: Procalcitonin to initiate or discontinue antibiotics in acute respiratory tract infections. Cochrane Database Syst Rev 9:CD007498, 2012.

Thikkurissy S, Rawlins JT, Kumar A, Evans E, Casamassimo PS: Rapid treatment reduces hospitalization for pediatric patients with odontogenic-based cellulitis. Am J Emerg Med 28:668 $-672,2010$.

Yu C-W, Juan L-I, Wu M-H, Shen C-J, Wu J-Y, Lee C-C: Systematic review and meta-analysis of the diagnostic accuracy of procalcitonin, C-reactive protein and white blood cell count for suspected acute appendicitis. Br J Surg 100:322-329, 2013. 
Table 1 : Facial cellulitis population description $(\mathbf{n}=\mathbf{7 0})$. Data are expressed as mean $\pm S D$, number (\%), median [interquartile $25 ; 75$ ], (extremes). NSAI : non steroidal antiinflammatory




Figure 1 : PCT receiver operating characteristics curves. Panel A: need for surgical drainage.

Panel B: hospital length of stay > mean + SD and/or need for reoperation. 
Figure 1



Panel A 


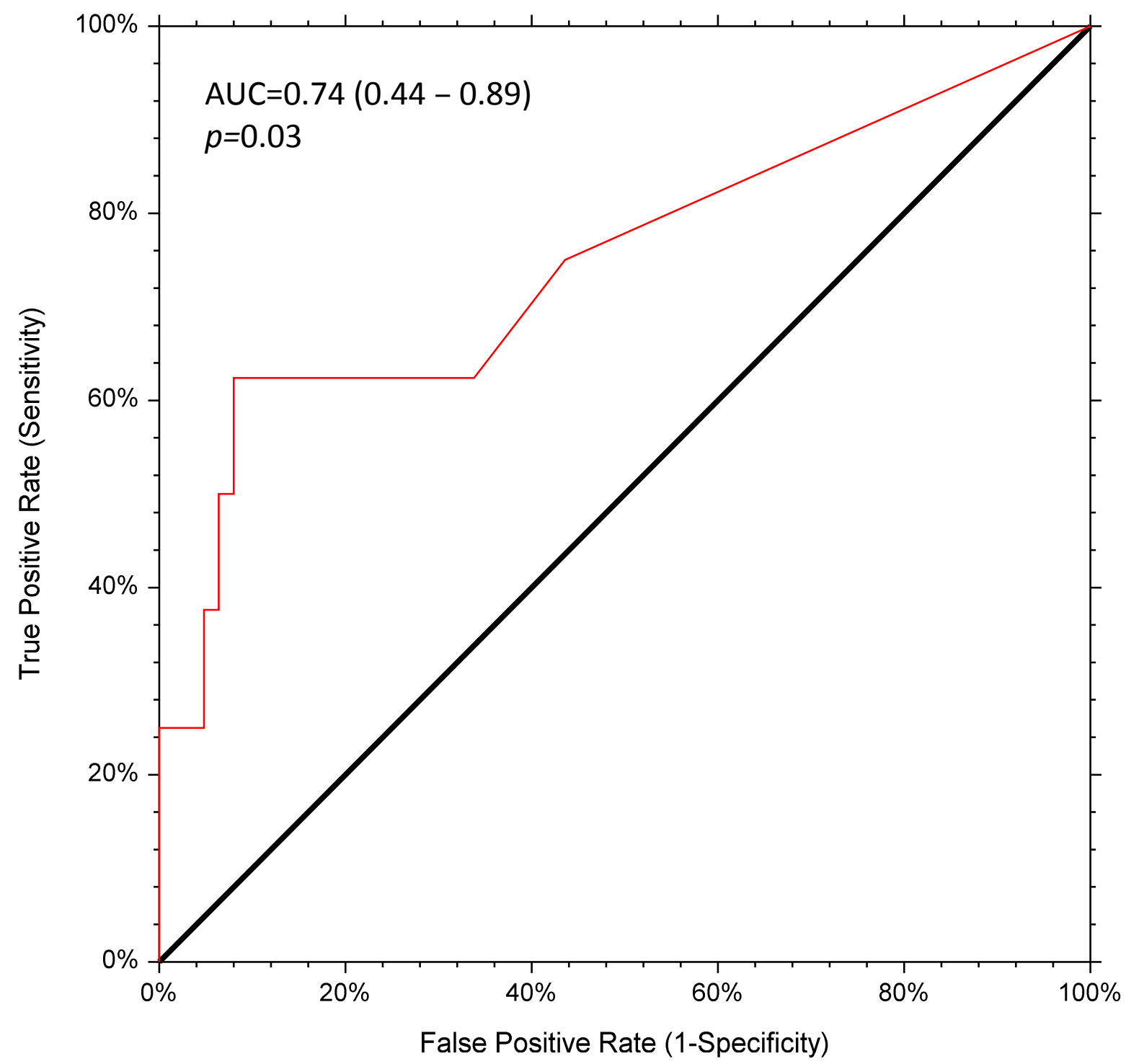

Panel B 